\title{
Crop Coefficients, Growth Rates and Quality of Cool- season Turfgrasses
}

\author{
T.S. Aamlid ${ }^{1}$, J.W. Knox ${ }^{2}$, H. Riley ${ }^{3}$, A. Kvalbein ${ }^{1}$ \& T. Pettersen ${ }^{1}$
}

${ }^{1}$ Norwegian Institute for Agricultural and Environmental Research, Bioforsk Landvik, Grimstad, Norway

${ }^{2}$ Departement of Environmental Science and Technology, Cranfield University, Bedfordshire, UK

${ }^{3}$ Norwegian Institute for Agricultural and Environmental Research, Bioforsk Apelsvoll, Kapp, Norway

Corresponding author:

T.S. Aamlid

Bioforsk Landvik, Reddalsveien 215

N-4886 Grimstad, Norway

Tel: +4790528378

E-mail: trygve.aamlid@bioforsk.no

Running title: Turfgrass crop coefficients

Number of Tables: 9

Number of Figures: 3 


\section{Abstract}

Determination of crop coefficients $(\mathrm{Kc})$, the ratio between actual $\left(\mathrm{ET}_{\mathrm{a}}\right)$ and reference evapotranspiration $\left(\mathrm{ET}_{0}\right)$, is necessary to schedule irrigation. Our objective was to determine Kc, turf quality and growth rate under daily irrigation to field capacity (FC $=-3 \mathrm{kPa}$ tension) and drying. Mini-lysimeters installed in a green (mowing height 3$5 \mathrm{~mm})$ and fairway $(15 \mathrm{~mm})$ were weighed during four periods of 4-10 days duration in 2009 and 2010. Crop coefficients on the second and subsequent days after irrigation were not significantly different among species and averaged 0.81 and 0.91 on green and fairway, respectively. On the first day after irrigation, the Kc varied from 1.67 to 2.85 and decreased in the order Agrostis capillaris > Festuca rubra ssp. litoralis $>$ F. rubra ssp. commutata $>$ A. stolonifera $>$ A. canina on the green, and F.rubra ssp. litoralis $>$ Lolium perenne $>$ F. rubra ssp. rubra $>$ Poa pratensis $>$ F. rubra ssp. commutata on the fairway. Drying reduced the average daily height growth from 0.98 to $0.74 \mathrm{~mm}$ on the green and 1.97 to $1.72 \mathrm{~mm}$ on the fairway. Scores for turf quality were reduced but remained acceptable. Although the Kc during the first day after irrigation to FC may be over-estimated due to latent soil heat and a possible oasis effect, we conclude that irrigation to FC should be avoided as it causes excessive water use.

\section{Keywords}

evapotranspiration; golf; irrigation; mini-lysimeters; mowing height; Scandinavia 


\section{Introduction}

Globally, the availability and cost of irrigation water are the most serious threats to further expansion of golf courses and other turfgrass areas. Many golf courses in Denmark, Spain and other European countries are already facing restrictions on irrigation abstraction with a changing climate only likely to exacerbate the situation (Rodriguez Diaz et al. 2010, Strandberg et al. 2012). Even in Scandinavia where water sources are generally abundant, turf quality is often compromised by an insufficient capacity of the public water supply system to meet peak irrigation demands during dry summers. On the other hand, unconstrained access to water may also result in excessive irrigation practices (over-irrigation), that lead to poor root development, disease pressure, nutrient and pesticide leaching and reduced playing quality (e.g. Espevig and Aamlid 2012a,b).

Methods used by turfgrass managers to determine irrigation water requirements vary. In many cases, water is applied for a defined period every night or every other night without knowledge of crop demand or recognition of the amount of water added (M. Frisk, irrigation specialist, Swedish Golf Federation, personal communication, June 2014). More experienced turfgrass managers adjust the irrigation settings on a daily basis depending on in-situ measurements of soil water content (SWC) in combination with visual assessments of turfgrass attributes such as turgidity or color.

Scheduling irrigation based on evapotranspiration (ET) rates is widely used in agriculture and turf management. Evaporation pans or atmometers of various types have been used in many environments (e.g. Fry \& Huang 2004, Riley and Berentsen 2009, Knox et al. 2011, Espevig \& Aamlid 2012a,b), but are gradually being 
replaced by automatic weather stations to calculate reference evapotranspiration $\left(\mathrm{ET}_{0}\right)$ from climate data using the original (Penman 1948) or modified versions of the Penman equation (Allen et al. 1989, Qian et al. 1996). A widely used version is FAO 56, developed by the United Nations Food and Agricultural Organization (Allen et al. 1994). According to FAO 56, the 'reference' surface is a hypothetical crop with assumed height of $12 \mathrm{~cm}$ closely resembling an extensive surface of green grass that is actively growing, completely shading the ground and not short of water (Allen et al. 1994).

To calculate actual ET $\left(\mathrm{ET}_{\mathrm{a}}\right)$ from a non-water-limited turfgrass surface, reference ET is multiplied by a crop coefficient $(\mathrm{Kc})$ describing the characteristics that distinguish the canopy from the reference surface, thus $\mathrm{ET}_{\mathrm{a}}=\mathrm{ET}_{0} \mathrm{x} \mathrm{Kc}$. Published Kc values vary from 0.8 to 1.3 for cool-season turfgrasses and from 0.6 to 0.8 for warm-season grasses (Aronsen et al. 1987b, Carrow 1995, Brown et al. 2001, Sass and Horgan 2006, Ebdon and DaCosta 2014). Kc values will normally increase with mowing height as a greater leaf area translates into more stomata (Feldhake et al. 1983, Orick and Throssell 1991, Ebdon and DaCosta 2014), but this effect may be counteracted by reduced rooting at lower mowing heights (Fry and Huang 2004). Fry and Butler (1989) reported a $12 \%$ increase in water use of annual bluegrass (Poa апnиа) and creeping bentgrass (Agrostis stolonifera) 'Penncross' as the mowing height was raised from 6 to $12 \mathrm{~mm}$.

Actual evapotranspiration $\left(\mathrm{ET}_{\mathrm{a}}\right)$ from a turfgrass canopy can also be determined by weighing mini-lysimeters filled with undisturbed soil at regular intervals (Feldhake et al. 1983, 1984, Qian et al. 1996, Kim and Beard 1988, Aronson et al. 1987a, b; Bremer 2003; Ebdon and DaCosta 2014). Such studies have shown that $\mathrm{ET}_{\mathrm{a}}$ on any date during a drying cycle depends not only on turfgrass species, but also 
on soil water content and thus irrigation frequency (Biran et al. 1981). Using minilysimeters, $0.245 \mathrm{~m}$ in diameter, $0.28 \mathrm{~m}$ deep and equipped with tensiometers at 10 cm depth, a study in New England (USA) found that Kc levels started to decline at matric potentials of approximately $-40,-60$ and $-80 \mathrm{kPa}$ in Kentucky bluegrass ( $\mathrm{Poa}$ pratensis), perennial ryegrass (Lolium perenne) and chewings fescue (Festuca rubra ssp. commutata), respectively (Aronson et al. 1987a). Crop coefficients of coolseason grasses were unaffected by soil water potential in the range -10 to $-50 \mathrm{KPa}$ and the authors therefore defined 'well-watered conditions' as any soil water potential higher than $-40 \mathrm{kPa}$. In their studies, the mini-lysimeters were drained for $24 \mathrm{~h}$ after saturation before weighing and starting the drying cycles. However, this does not seem particularly relevant after saturation of a USGA specification green (USGA 2004), in which the soil water potential at field capacity varies from $-1 \mathrm{kP}$ at the bottom to $-4 \mathrm{kPa}$ at the top of the sand-based rootzone (Bigelow et al. 2001).

Studies in the USA have shown that the Kc value of well-watered turf of the same species varies depending on season and between climatic regions, suggesting that regional values should be derived to ensure optimal irrigation efficiency (Carrow 1995, Brown et al. 2001, Ebdon and DaCosta 2014). Thus, the objective of this research was to determine Kc values, under both well-watered conditions and during drying, of the most widely used turfgrass species used on the greens and fairways on Scandinavian golf courses.

\section{Materials and Methods}

\section{Experimental site}


The study was conducted during the growing seasons 2009 and 2010 on an experimental green and fairway at the Bioforsk Turfgrass Research Centre Landvik, Grimstad, Norway $\left(58^{\circ} 20^{\prime} \mathrm{N}, 8^{\circ} 32^{\prime} \mathrm{E}, 12 \mathrm{~m}\right.$ a.s.1.). The green and fairway were located 20-30 m apart. The experimental green was constructed in 2007 with a $30 \mathrm{~cm}$ sand-based and peat-amended rootzone above a $10 \mathrm{~cm}$ gravel layer (USGA 2004). On 17 August 2007 the green was split into five sections and seeded with chewings fescue 'Center', slender creeping red fescue (F. rubra ssp. litoralis syn. trichophylla) 'Cezanne', colonial bentgrass (Agrostis capillaris) 'Barking', velvet bentgrass (Agrostis canina) 'Legendary' and creeping bentgrass 'Independence', respectively. The soil on the fairway was a silt loam (64\% sand, $29 \%$ silt, $7 \%$ clay). From seeding in July 2005 until October 2008, the area had been used in another trial comparing different species and varieties. In May 2009, chewings fescue 'Center', slender creeping red fescue 'Barcrown', strong creeping red fescue (F. rubra ssp. rubra) 'Celianna', perennial ryegrass 'Bargold' and Kentucky bluegrass 'Limousine' were retained for use in this study.

\section{Maintenance of green and fairway}

During the measurement periods in 2009 and 2010, the green was cut on Mondays, Wednesdays and Fridays with a walk-behind green mower at $3 \mathrm{~mm}$ (bentgrasses) or $5 \mathrm{~mm}$ (fescues) mowing height. The fairway was cut on Mondays and Fridays to 15 $\mathrm{mm}$ with a triplex mower without collection of clippings. Mowing was always conducted shortly after reinsertion of the mini-lysimeters (see later). After mowing, the turf was also exposed to abrasive wear from a wear machine with golf spikes mounted on two drums rotating at different speed. The amount of wear corresponded to approximately 20.000 rounds of golf per year. 
The green received weekly applications of liquid and granular fertilizer corresponding to a seasonal rate of $16 \mathrm{~g} \mathrm{~N} \mathrm{~m}^{-2}$ to all species in 2009 and $15 \mathrm{~g} \mathrm{~N} \mathrm{~m}^{-2}$

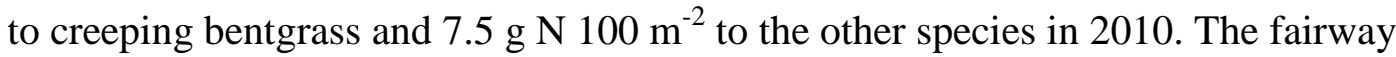
received granular fertilizer every second week in 2009 and every third week in 2010, with the total inputs corresponding to 12 and $10 \mathrm{~g} \mathrm{~N} \mathrm{~m}^{-2}$, respectively.

\section{Physical soil analyses}

Three undisturbed soil cores, $37 \mathrm{~mm}$ deep and $55 \mathrm{~mm}$ diameter, were taken at each of four depths on the green and at each of two depths on the fairway and then analyzed in the soil laboratory at Bioforsk Apelsvoll Research Center, as described by Riley (1996). The analyses showed a higher air-filled porosity and saturated hydraulic conductivity, but a lower plant available water capacity in the $10-1500 \mathrm{kPa}$ tension range on the green compared to the fairway (Table 1). The ignition loss was on average three times higher on the fairway than on the green. Higher bulk density and lower hydraulic conductivity at 150-187 than at 27-64 mm depth on the fairway was associated with a tendency for the formation of a hard pan. The experimental area had been used for arable farming with annual ploughing until the fairway was established in 2005.

\section{Root dry weight}

Samples for determination of root dry weight in various layers were taken before the first registration period in May/June 2009. Three undisturbed cores, $56 \mathrm{~mm}$ in diameter and $30 \mathrm{~cm}$ deep, were extracted from each species on the green and on the fairway. The cores were cut immediately below the thatch/mat layer and at 5,10 and 
$20 \mathrm{~cm}$ depths. Roots were washed carefully and root weight in each layer determined after drying at $60^{\circ} \mathrm{C}$ for $48 \mathrm{~h}$. The effective root depth was defined as $20 \mathrm{~cm}$ in all species, as virtually no roots could be found at greater depth in samples from either green or fairway.

\section{Measuring actual evapotranspiration $\left(\mathbf{E T}_{\mathrm{a}}\right)$}

Six mini-lysimeters (metal cylinders), each $30 \mathrm{~cm}$ deep and $10 \mathrm{~cm}$ in diameter, were inserted randomly in each of the five grass species/subspecies on the green in November 2008 and in in each of the five grass species/subspecies on the fairway in May 2009. Thus, our experimental approach includes observations of 60 minilysimeters altogether. One special cylinder with sharpened edges was inserted into the soil and the intact, undisturbed profile then transferred carefully to a permanent mini-lysimeter containing fine wire-mesh at the base. In order to prevent the pit from collapsing when the mini-lysimeter was extracted, each mini-lysimeter was surrounded by a metal sleeve with a diameter $5 \mathrm{~mm}$ wider than the mini-lysimeter. The top of the mini-lysimeters and sleeves were at ground level thus allowing mowing practices to be carried out as usual.

As the mini-lysimeters were not set up to collect drainage water, nor covered in the event of rain, the determination of turfgrass water use could only be accomplished during periods without rainfall. In 2009, we collected daily values for $\mathrm{ET}_{\mathrm{a}}$ during three periods, 27 May - 2 June, 24 June - 2 July and 10-14 August. The experimental protocol during these periods was as follows:

1. On the first day of each evaluation period, all mini-lysimeters were removed from their sleeves at around 11:00h and hand-watered gently and repeatedly using a fine spray nozzle until water dripped through the fine mesh at the 
bottom. After this, the mini-lysimeters were allowed to drain for one hour before re-weighing and reinsertion into their sleeves, usually at around 13:00h. In this study, the soil water content after one hour's drainage is referred to as 'field capacity' (FC).

2. On subsequent days, the mini-lysimeters were removed and then weighed at approximately 11:00. After weighing, three mini-lysimeters per species were watered to FC following the procedure described above (1) before reinsertion . The remaining three cylinders were reinstalled without irrigation (drying treatment).

3. In the green trial, the turf surrounding the mini-lysimeters was irrigated two to three times per week using an overhead sprinkler system once the cylinders had been removed for weighing. Irrigation of the surrounding turf was not possible on the fairway trial as the lysimeter holes would have filled with water due to the limited hydraulic conductivity of the compact soil layer at $15-20 \mathrm{~cm}$ depth.

4. During the first observation period (27 May - 2 June 2009) we found that turfgrass water use was much higher than expected for cylinders that were watered daily to FC. Therefore, it was questioned whether some of the weight loss was due to drainage from the cylinders after reinstallation into the sleeves. During the subsequent observation periods, the bottom of each cylinder was sealed with a plastic bag to collect any drainage water; however, we observed virtually no water in these plastic bags.

In 2010, measurements of turfgrass $\mathrm{ET}_{\mathrm{a}}$ were conducted from 20 May to 30 May on the green and from 20 May to 9 June on the fairway. As with the two last measurement periods in 2009 , the cylinder bases were sealed with plastic bags to 
prevent drainage. Three of the six cylinders were watered back to FC twice each week; the remaining three were subjected to progressive drying (no irrigation) with irrigation to FC only at the start of the measurements. Registrations on the green also included six cylinders located on nearby plots where the USGA-specification sand had been exposed because the turf had been removed due to winter damage.

\section{Reference ET-values $\left(\mathbf{E T}_{\mathbf{0}}\right)$ and crop coefficients $(\mathrm{Kc})$}

Daily values for $\mathrm{ET}_{0}$ were calculated for Landvik weather station (ca. $200 \mathrm{~m}$ from the green and fairway) using the FAO 56 version of the Penman-Monteith equation (WaSim software, Cranfield University, UK). Daily crop coefficients for irrigated and unirrigated turf for each species during the measurement periods were calculated as $\mathrm{Kc}=\mathrm{ET}_{\mathrm{a}} / \mathrm{ET}_{0}$, where $\mathrm{ET}_{\mathrm{a}}$ is the actual and $\mathrm{ET}_{0}$ the reference evapotranspiration, respectively.

\section{Turfgrass growth rate and turfgrass quality}

Turfgrass height was measured using a Turf Check Prism device (Check Signature Inc., Shoreview, MN, USA) before mowing on Mondays, Wednesdays (green only) and Fridays during each measurement period. Growth rates were expressed as the daily height increment based on the bench settings of the mowers used on the green and fairway, respectively. At the end of each measurement period, turf quality was rated on a scale from 1-9, where 5 was the lowest acceptable quality.

\section{Statistical analyses}

Data for thatch thickness and root weight in various layers were subjected to oneway analyses of variance (PROC ANOVA, SAS Institute, Cary, NC, USA) with 
turfgrass species as the fixed factor with five levels. These analyses were performed on the assumption that that the root samples were uncorrelated and independent as the physical soil analyses showed very uniform conditions within the green and within the fairway. Crop coefficients were analyzed as two separate data sets, one for the mini-lysimeters that were irrigated back to FC on a daily basis (three periods in 2009) or twice per week (2010), and the other for the mini-lysimeters that were subjected to progressive drying. In the first dataset, Kc values were averaged over all days during each period (in 2010 only the first day after irrigation) before analysis. In the second dataset, values were averaged for the second and subsequent days during the dry-down cycle, thus excluding the first $24 \mathrm{~h}$ after irrigation back to FC. The analyses were performed using the SAS PROC MIXED, with turfgrass species as the fixed variable and mini-lysimeter number within species (1-3) and measurement period (1-4) as the random variables. Possible correlations due to repeated observations on the same mini-lysimeter were modelled by either the UN (unstructured) or the auto-regressive (AR(1)) options of the REPEATED statement in PROC MIXED, whichever gave the lower AIC-value, and mean Kc values for turfgrass species were then estimated using the LSMEANS procedures.

Data for daily height increment and turfgrass quality at the end of each observation period were modelled using PROC MIXED, again using the REPEATED statement to ensure independency among observations. For these variables, not only turfgrass species, but also irrigation treatment and their interaction were regarded as fixed effects. Tukey's HSD at $P=0.05$ was used to identify any significant differences between treatments for all response variables. In this paper the term 'significant' refers to $P \leq 0.05$, but higher $P$-values, up to $\mathrm{P}=0.15$, have also been shown in the tables. 


\section{Results}

\section{Root dry weight}

The measured differences in root dry weight between the turf species were significant at both sites. Most roots were found in the thatch/mat layer, the weight of which was especially high in velvet bentgrass on the green (Table 2), and in the chewings fescue and slender creeping red fescue on the fairway (Table 3). Below the thatch/mat layer, chewings fescue and velvet bentgrass had the highest root weight on the green, while perennial ryegrass had significantly more roots than Kentucky bluegrass and strong creeping red fescue on the fairway.

\section{Turfgrass ETa in treatments with irrigation to FC and during drying}

Actual values of turfgrass water use on the green and fairway during the measurement period 10-14 August 2009 are shown in Fig. 1. On both green and fairway, the $\mathrm{ET}_{\mathrm{a}}$ from the mini-lysimeters that received daily irrigation back to $\mathrm{FC}$ showed considerable day to day variation but were on average for the period between 50 and $300 \%$ higher than the reference value $\mathrm{ET}_{0}$. By contrast, the mini-lysimeters that were only irrigated at the start of the measurement period showed a characteristic drop in water use with time. From the second or third day after irrigation back to $\mathrm{FC}$, the $\mathrm{ET}_{\mathrm{a}}$ on the unirrigated plots was mostly lower than the $\mathrm{ET}_{0}$. Data from the two first measurement periods in 2009 are not included as they showed similar patterns.

$\mathrm{ET}_{\mathrm{a}}$ values for the period 20 - 30 May 2010 (green) and 20 May - 9 June 2010 (fairway) for treatments irrigated back to FC twice per week and without irrigation are shown in Fig 2. As in 2009, turfgrass water use was two to four times higher than 
$\mathrm{ET}_{0}$ on the first day after irrigation back to FC. The lowest water use on the first day after irrigation to FC was found in velvet bentgrass on the green and in chewings fescue and Kentucky bluegrass on the fairway. $\mathrm{ET}_{\mathrm{a}}$ from the mini-lysimeters without turf cover (bare soil) on the green was two to three times higher than $\mathrm{ET}_{0}$ on the first day after irrigation to $\mathrm{FC}$, but lower than $\mathrm{ET}_{0}$ on subsequent days.

The differences in Kc values between the turfgrass species are shown in Table 4. Differences on the first day after irrigation to FC were significant on the fairway and almost significant $(P=0.055)$ on the green. On this day, chewings fescue took up less water than any other turfgrass species on the fairway, while velvet bentgrass took up less water than any other species on the green. On the second and subsequent days after irrigation to FC, differences between species were not significant on either green or fairway, but there was a tendency for chewings fescue to use more water than the other species on the green.

\section{Turfgrass growth rate}

On average for species and the four measurement periods, withholding irrigation reduced the turfgrass growth rate significantly by $24 \%$ on the green (Table 5) and by $13 \%$ on the fairway (Table 6). Differences among turfgrass species were significant on the green, where red fescues, especially chewings fescue, and colonial bentgrass, grew more strongly in height than did creeping and velvet bentgrass. Differences in height growth on the fairway were almost significant $(P=0.065$, Table 6$)$ as there was a tendency for perennial ryegrass and strong creeping red fescue to grow more strongly than the Kentucky bluegrass, while chewings fescue and slender creeping red fescue were intermediate. The interaction between species and irrigation 
treatments was not found to be significant on either green or fairway.

\section{Turfgrass quality}

Withholding irrigation reduced turfgrass quality significantly on the fairway (Table $8)$ and showed a similar tendency $(P=0.14)$ on the green (Table 7). However, the quality scores remained higher than $5.0(=$ acceptable) for all species in both trials. Velvet bentgrass had higher scores than the other species in the green trial; its overall impression also showed negligible effects of drying. The interactions between species and irrigation treatment were not significant in any of the trials.

\section{Discussion}

\section{Possible reasons for high Kc-values on the first day after irrigation back to FC}

The crop coefficients for the second and following days after irrigation back to FC, $0.76-0.87$ on the green and $0.84-0.99$ on the fairway were similar to those reported earlier for cool-season grasses (Aronson et al. 1987b, Brown 2001, Sass and Horgan 2006). In contrast, Kc values on the first day after irrigation to $\mathrm{FC}$ were higher than any previously reported. This is most likely due to the fact that the mini-lysimeters were left to drain for only one hour after irrigation before sealing the base and returning them back to the turfgrass plots. Other researchers (Aronson et al. 1987a, b, Bremer 2004) allowed the turf to drain for $24 \mathrm{~h}$ before returning the mini-lysimeters back into the turf; this likely removed some of the easily available water that would otherwise have been used by the turf. A $24 \mathrm{~h}$ drainage period before the start of measurements might be reasonable on heavy agricultural soils with infrequent 
irrigation and if the soil in the mini-lysimeters is in hydraulic contact with the underlying soil, but not on sand-based USGA greens that have a maximum hydraulic head of $4 \mathrm{kPa}$ (Bigelow et al. 2001) and a more frequent irrigation schedule than agricultural soils. In the fairway trial, the fact that root development in the minilysimeters was restricted by a compact layer with poor drainage at about $20 \mathrm{~cm}$ depth, helps to substantiate our conclusion that FC should be based on the $-3-1500$ $\mathrm{kPa}$ rather than the $-10-1500 \mathrm{kPa}$ tension range. During the measurement periods $2-4$, the plastic bags used to seal the base of the lysimeters contained virtually no drainage water, so there is little doubt that the water loss on the first day after irrigation to FC was due to evapotranspiration, perhaps also with a marginal contribution from guttation water which has been shown to increase with turf density, soil temperature and soil water content (Hughes and Brinklecombe 1994). We therefore contend that inclusion of the easily available water in the $3-10 \mathrm{kPa}$ tension range, which contributed about 35 and $25 \%$ of the total FC on the green and fairway, respectively, was an important source of the high water loss on the first day after irrigation to FC. This reflects typical conditions with frequent irrigation used on many golf courses.

Earlier investigations by Bremer (2003) have shown that gravimetric determination of actual water use depends on mini-lysimeter design, including diameter, depth and construction material, and even the leaf area index and shoot and root biomass within the mini-lysimeters compared with those of the surrounding turf. In order to obtain robust measurements, the authors recommended using minilysimeters filled with intact (undisturbed) soil cores and sealed bases rather than draining mini-lysimeters filled with soil and prepared in the greenhouse before use in the field. As these recommendations were adopted in our study, the high Kc rates on the first day after filling the soil reservoir to FC cannot be ascribed to either drainage 
or to higher biomass in the mini-lysimeters than in their surroundings. However, on the fairway trial, the surrounding turf was not irrigated after mini-lysimeter removal, as the holes would have filled with water due to low infiltration rates. This may well have resulted in an 'oasis effect' when the freshly irrigated mini-lysimeters were reinstalled into the dry surrounding soil. This was especially apparent in 2010 when the lysimeters were visible as small 'green islands' in an otherwise dry and brownish fairway by the end of the measurement period between 20 May and 9 June. We have later tried to quantify this 'oasis effect' by comparing the weight loss from six minilysimeters filled with undisturbed cores of chewings fescue 'Center', three installed in a well-irrigated fairway and three in an open field with a dry surface of bare soil. This small trial showed about $20 \%$ higher water use on the first day after installation in dry versus wet surrounding soil, which may well be viewed as an indication of the over-estimation in Kc values on the first day after irrigation back to FC in the fairway trial.

The upper limit for the amount of water that can be evaporated into the atmosphere from an open surface is determined by the global radiation intercepted by the surface. The FAO 56 equation uses a factor $(0.408)$ to convert radiation $\left(\mathrm{MJ} \mathrm{m}^{-2}\right)$ into 'evaporation equivalents' (mm) (Allen et al. 1994). Table 9, based on records of global radiation at the Landvik weather station, show that the average measured $\mathrm{ET}_{\mathrm{a}}$ was below this limit in the early summer of 2009, but above the limit in August 2009 and May 2010. The soil temperature in the mini-lysimeters was not recorded, but standard measurements at $10 \mathrm{~cm}$ soil depth at the Landvik weather station showed values of $12.3,17.1$, and $18.4{ }^{\circ} \mathrm{C}$ at the start of the three measurement periods in 2009 , respectively. Thus, in addition to the oasis effect, one possible explanation why the theoretical ET limit was exceeded in August 2009 may be that latent heat 
stored in, and perhaps around, the mini-lysimeters resulted in higher ET-rates. On the green where the upper edges of the mini-lysimeters and surrounding sleeves were less covered by grass leaves than on the fairway, this might also include any possible direct effect of radiation on the temperature of the metal used in the mini-lysimeters and sleeves. Feldhake and Boyer (1986) observed a strong effect of soil temperature on ET rates, and Riley and Berentsen (2009) found a seasonal trend that the Penman model over-estimated pan evaporation in spring and early summer, but then underestimated evaporation rates in late autumn. During May 2010, the mini-lysimeters were replenished to FC twice weekly instead of every day as in 2009; this may also have allowed more latent heat to build up between successive irrigations. This could be observed even in the mini-lysimeters that that had no turf cover but where the $\mathrm{ET}_{\mathrm{a}}$ on the first day after irrigation back to $\mathrm{FC}$ was two to three times higher than $\mathrm{ET}_{0}$. For the latter, it is, however, worth noting that drying of the surface caused the evaporation rate to decrease below the reference value and the $\mathrm{ET}_{\mathrm{a}}$ from turfgrass canopies on the second and subsequent days after irrigation.

Hyperbolic functions describing Kc values for unirrigated turf during the first week after irrigation back to FC are shown in Fig. 3. Except for slender creeping red fescue and perennial ryegrass which on the fairway had 0.61 and 0.73 , respectively, coefficients of determination were always higher than 0.80 . In most cases the models suggest that crop coefficients below 1.0 were not reached until the third day after irrigation to FC.

\section{Effects of turfgrass species and mowing heights}

The generally higher $\mathrm{ET}_{\mathrm{a}}$ values measured on the fairway compared to the green agree with findings from Feldhake et al. (1983), Orick and Throssell (1991), and 
Ebdon and DaCosta (2014). They found that higher mowing, and thus a higher leaf area index, results in higher Kc values. However, chewings fescue 'Center', the only variety that was studied at both mowing heights, was an exception. It used more water on the green than on the fairway during the first day after irrigation back to FC and approximately the same amount of water on subsequent days. Red fescues are usually considered to be among the more drought resistant turfgrasses because of their fine leaves (Kim and Beard 1988, Fry and Huang 2004), but our data, along with those of Blankenship (2011), suggest that the water-saving effect of narrow leaves becomes less important at low mowing heights. Our data also showed considerable variation among the cultivars representing various sub-species of red fescue, especially on the fairway where slender creeping red fescue 'Barcrown' and strong creeping red fescue 'Celianna' transpired significantly more water on the first day after irrigation back to FC than chewings fescue 'Center'. The turfgrass growth rate and overall impression during drying was also less affected in 'Barcrown' than in 'Center', despite the fact that 'Center' had a higher root mass. Although the best drought avoidance in the fairway trial was found in perennial ryegrass, which also had the most extensive root system, our results for the red fescues support similar findings with Kentucky bluegrass cultivars (Richardson et al. 2008); namely, that turfgrass water use is often better correlated with turfgrass canopy characteristics than with rooting capacity (Kim and Beard 1988), at least during the first days after replenishment to FC. Deeper roots in chewings fescue than in the creeping subspecies of red fescue agrees with with Boeker (1974), but our results showed an effect of root development on drought resistance of the different sub-species of red fescue only at the mowing height used on the green. 
Finally, in the green trial, velvet bentgrass had significantly lower crop coefficients on the first day after irrigation back to FC than had the colonial bentgrass and red fescues. One possible reason is that the extremely high tiller density and thick thatch layer in velvet bentgrass resulted in a more humid microclimate with a thicker boundary layer that limited transpiration. The large difference in crop coefficients among the bentgrasses on the first day after irrigation back to FC supports DaCosta and Huang (2006) who found that $\mathrm{ET}_{\mathrm{a}}$ increased in the order velvet bentgrass < creeping bentgrass $<$ colonial bentgrass. Shearman and Beard (1972) also found that that velvet bentgrass had a lower stomatal density than other cool-season turfgrasses.

\section{Conclusion}

This research has shown that crop coefficients for cool season grasses on a green and fairway are up to three times higher on the first day than on the second and subsequent days after irrigation back to FC. Frequent irrigation back to FC would thus lead to excessive water use that cannot be justified by a corresponding increase in turf quality. Crop coefficients for cool season turfgrass species vary significantly on the first day after irrigation back to FC due to differences in canopy characteristics, but there is less variation on subsequent days. The findings have important implications for the turfgrass industry in promoting more sustainable management and efficient use of water and helping reduce the environmental impacts associated with over-irrigation.

\section{Acknowledgements}


This research was funded by the Scandinavian Turfgrass and Environment Research Foundation (STERF) and grant no 192272/110 from the Research Council of Norway. We thank Mr. Torfinn Torp for help with the statistical analyses.

\section{References}

Allen, R.G., M.E. Jensen, J.L. Wright, and R.D. Burman, 1989: Operational estimates for evapotranspiration. Agron. J. 81, 650-662.

Allen, R.G., L.S. Pereira, D. Raes, and M. Smith, 1994: Crop evapotranspiration. Guidelines for computing crop water requirements. FAO Irrigation and Drainage Paper 56. Rome. 300pp.

Aronsen, L.J., A.J. Gold, and R.J. Hull, 1987a: Cool season turfgrass responses to drought stress. Crop Sci. 27, 1261-1266.

Aronsen, L.J., A.J. Gold, R.J. Hull, and J.L. Cisar, 1987b: Evapotranspiration of cool-season turfgrasses in the Humid Northeast. Agron. J. 79, 901-905.

Bigelow, C.A., D.C. Bowman, and D.K Cassel, 2001: Water retention of sand-based putting green mixtures as affected by the presence of gravel sub-layers. Int. Turf. Soc. Res. J. 9, $479-486$.

Biran, I., B. Bravdo, I. Bushkin-Harav, and E. Rawitz, 1981: Water consumption and growth rate of turfgrasses as affected by mowing height, irrigation frequence and soil water content. Agron. J. 73, 85-90.

Blankenship, T.M., 2011: Water use characteristics of ten newly established coolseason turfgrass species. M.S. Thesis: Oregon State University. 108 pp.

Boeker, P., 1974. Root development for selected turfgrass species and cultivars. In:

E.C. Roberts (ed.): Proc. Sec. Int. Turf. Res. Conf. pp. 55-61. 
Bremer, D.J., 2003: Evaluation of microlysimters used in turfgrass

evapotranspiration studies using the dual-probe heat-pulse technique. Agron. J. $95,1625-1632$.

Brown, P.W., C.F. Mancino, M.H. Young, T.L. Thompson, P.J. Wierenga, and D.M. Kopec, 2001: Penman Monteith crop coefficients for use with desert turf systems. Crop Sci. 41, 1197-1206.

Carrow, R.N., 1995: Drought resistance aspects of turfgrasses in the southeast: evapotranspiration and crop coefficients. Crop Sci. 35, 1685-1690.

DaCosta, M., and B. Huang, 2006: Deficit irrigation effects on water use characteristics of bentgrass species. Crop Sci. 46: 1779-1786.

Ebdon, S., and M. DaCosta, 2014: Efficient irrigation of golf turf in the cool-humid New England region. USGA Turf. and Environ. Res. Online 13, 1-4.

Espevig, T., and T.S. Aamlid, 2012a: Effect of rootzone compostions and irrigation regime on performance of velvet bentgrass putting greens. I. Turf quality, soil water repellency and nutrient leaching. Acta Agric. Scand. Sect. B Soil \& Plant Sci. 62, 96-105. (Supplement 1).

Espevig, T., and T.S. Aamlid, 2012b: Effect of rootzone compostions and irrigation regime on performance of velvet bentgrass putting greens. II. Thatch, root development and playability. Acta Agric. Scand. Sect. B Soil \& Plant Sci. 62, 106-112. (Supplement 1).

Feldhake, C.M., R.E. Danielson, and J.D. Butler, 1983: Turfgrass evapotranspiration. I. Factors influencing rates in urban environments. Agron. J. $75,824-830$. 
Feldhake, C.M., R.E. Danielson, and J.D. Butler, 1984: Turfgrass evapotranspiration. II. Responses to deficit irrigation. Agron. J. 76, 85-89.

Feldhake, C.M., and D.G. Boyer, 1986: Effect of soil temperature on evapotranspiration by C3 and C4 grasses. Agric. Forest Meteorl. 37, 309-318.

Fry, J., and J.D. Butler 1989: Annual bluegrass and creeping bentgrass evapotranspiration rates. HortScience 24, 269-271.

Fry, J., and B. Huang, 2004: Applied turfgrass science and physiology. John Wiliey \& Sons, Hoboken, NJ, USA. 310 pp.

Hughes, R.N., and P. Brinblecombe, 1994: Dew and guttation: formation and environmental significance. Agric. Forest Meteorol. 67, 173-190.

Kim, K.S., and J.B. Beard, 1988: Comparative turfgrass evapotranspiration rates and associated plant morphological characteristics. Crop Sci. 28, 328-331.

Knox, J.W., J.A. Rodriguez-Diaz, and T.M. Hess, 2011: Estimating evapotranspiration by using atmometers for irrigation scheduling in a humid environment. Am. J. Irr. Drain. Eng. 137, 685-691.

Penman, H.L., 1948: Natural evapotranspiration from open water, bare soil and grass. Proc. Roy. Soc. London Ser. (A) 193, 120-146.

Qian, Y.L., J.D. Fry, S.C. Wiest, and W.S. Upham, 1996: Estimating turfgrass evapotranspiration using atmometers and the Penman-Monteith model. Crop Sci. 36, 699-704.

Orick, J.C., and C.S. Throssell, 1991: Water use rates and crop coefficients for coolseason turfgrass species influenced by mowing height Agr. Abs. 181. 
Richardson, M.D., D.E. Karcher, K.W. Hignight, and D. Rush, 2008: Drought tolerance and rooting capacity of Kentucky bluegrass cultivars. Crop Sci. 48, 2429-2436.

Riley, H., 1996: Derivation of physical properties of cultivated soils in SE Norway from readily available soil information. Norw. J. Agr. Sci. Supplement no. 25, 151.

Riley, H., and E. Berentsen, 2009: Estimation of water use for irrigation in Norwegian agriculture. Bioforsk Report 4 (174), 1-80.

Rodríguez-Díaz, J.A., E.K. Weatherhead, J. García Morillo, and J.W. Knox, 2010: Benchmarking irrigation water use in golf courses - a case study in Spain. Irrigation and Drainage 60, 381-392.

Sass, J.F., and B.P. Horgan, 2006: Irrigation scheduling on sand-based creeping bentgrass: Evaluating evapotranspiration estimation, capacitance sensors and deficit irrigation in the Upper Midwest. Appl. Turf. Sci. doi: 10.1094/ATS-20060330-01-RS.

Shearman, R.C., and J.B. Beard, 1972: Stomatal density and distribution in Agrostis as influenced by species, cultivar and leaf blade surface and position. Crop Sci. $12,822-823$.

Strandberg, M., K. Blombäck, A.M.D. Jensen, and J.W. Knox, 2012: The future of turfgrass management - challenges and opportunities. Acta Agric. Scand. Sect. B Soil \& Plant Sci. 62, 3-9. (Supplement 1).

USGA, 2004: USGA recommendations for a method of putting green construction. www.usga.org (verified 1 May 2014) 


\section{Figure legends:}

Fig. 1. Reference ET-values and daily water use $(\mathrm{mm})$ for five turfgrass species on green (a-e, left column) and fairway (f-j, right column) during the measurement period $10-14$ Aug. 2009. \pm 1 SE (standard error of the mean, $n=3$ ) has been indicated. Turfgrass water use refers to cylinder weight loss from 11:00-13:00 h on the actual day to 11:00-13:00 $\mathrm{h}$ on the day after. Reference $\mathrm{ET}_{0}$ values were calculated using data from the official Landvik weather stations and the FAO 56 Penman Monteith equation.

Fig. 2. Reference $\mathrm{ET}_{0}$-values and daily water use $(\mathrm{mm})$ for five turfgrass species and bare soil on green (a-f, left column) and five turfgrass species on fairway (g-k, right column) during the measurement period 20 - 30 May 2010. \pm 1 SE (standard error of the mean, $n=3$ ) has been indicated. Turfgrass water use refers to cylinder weight loss from 11:00-13:00 $\mathrm{h}$ on the actual day to 11:00-13:00 $\mathrm{h}$ on the day after. Reference $\mathrm{ET}_{0}$ values were calculated using data from the official Landvik weather stations and the FAO 56 Penman Monteith equation.

Fig. 3. Crop coefficients (Kc) of various turfgrass species on green (a) and fairway (b) as functions of day number after irrigation to field capacity. Data are means of four observation periods. 
Table 1. Physical parameters in undisturbed soil cores taken at four depths on green and two depths on fairway.

Values represent means of three replicate samples taken at each depth in June 2009.

\begin{tabular}{|c|c|c|c|c|c|c|c|c|c|}
\hline & $\begin{array}{l}\text { Sample } \\
\text { depth }\end{array}$ & $\begin{array}{c}\text { Loss } \\
\text { on } \\
\text { ignition }\end{array}$ & $\begin{array}{c}\text { Bulk } \\
\text { density } \\
\mathrm{g} \mathrm{cm}^{-3}\end{array}$ & $\begin{array}{c}\text { Sat. } \\
\text { hydraulic } \\
\text { conductivity }\end{array}$ & $\begin{array}{c}\text { Total } \\
\text { poro- } \\
\text { sity, }\end{array}$ & $\begin{array}{c}\text { Air-filled } \\
\text { porosity } \\
\text { at }\end{array}$ & $\begin{array}{c}\text { Unavailable } \\
\text { water at } \\
-1500\end{array}$ & $\begin{array}{r}\text { Plant } \\
\text { wate } \\
\text { capac }\end{array}$ & $\begin{array}{l}\text { vailable } \\
\text { at field } \\
y, \text { vol\% }\end{array}$ \\
\hline & $\mathrm{mm}$ & $\%$ & & $\begin{array}{c}\left(\mathrm{K}_{\mathrm{sat}}\right) \\
\mathrm{mm} \mathrm{h}^{-1}\end{array}$ & vol\% & $\begin{array}{c}-3 \mathrm{kPa} \\
\text { vol\% }\end{array}$ & $\begin{array}{l}\mathrm{kPa}, \\
\mathrm{vol} \%\end{array}$ & $\begin{array}{c}-3-10 \\
\mathrm{kPa}\end{array}$ & $\begin{array}{c}-10-1500 \\
\mathrm{kPa},\end{array}$ \\
\hline \multirow[t]{4}{*}{ Green } & $13-50$ & 1.38 & 1.58 & 208 & 44.6 & 31.5 & 2.2 & 3.6 & 7.3 \\
\hline & 55-92 & 1.02 & 1.59 & 197 & 41.6 & 29.3 & 1.6 & 3.6 & 7.1 \\
\hline & $105-142$ & 1.01 & 1.50 & 232 & 46.1 & 34.2 & 1.5 & 3.7 & 6.7 \\
\hline & $155-192$ & 1.06 & 1.44 & 235 & 46.8 & 35.0 & 1.5 & 3.8 & 6.5 \\
\hline Fair- & $27-64$ & 3.67 & 1.36 & 101 & 45.9 & 20.7 & 4.5 & 5.5 & 15.2 \\
\hline way & $150-187$ & 3.16 & 1.46 & 69 & 42.6 & 20.5 & 4.8 & 3.8 & 13.8 \\
\hline
\end{tabular}


Table 2. Root dry weight for selected turfgrass species on the green, June 2009

Values represent means of three replicate samples per species.

\begin{tabular}{lcccccc}
\hline & \multicolumn{5}{c}{ Root dry weight in various layers, $\mathrm{g} \mathrm{m}^{-2}$} \\
\cline { 2 - 7 } & In & Thatch - & & & Total under \\
Turfgrass species & thatch & $5 \mathrm{~cm}$ & $5-10 \mathrm{~cm}$ & $10-20 \mathrm{~cm}$ & thatch \\
\hline Chewings fescue & $609 \mathrm{~b}$ & $191 \mathrm{ab}$ & $106 \mathrm{a}$ & 113 & $410 \mathrm{a}$ \\
Slender creeping red fescue & $614 \mathrm{~b}$ & $158 \mathrm{~b}$ & $63 \mathrm{~b}$ & 81 & $302 \mathrm{ab}$ \\
Colonial bentgrass & $538 \mathrm{~b}$ & $154 \mathrm{~b}$ & $82 \mathrm{ab}$ & 93 & $329 \mathrm{ab}$ \\
Creeping bentgrass & $474 \mathrm{~b}$ & $144 \mathrm{~b}$ & $63 \mathrm{~b}$ & 38 & $244 \mathrm{~b}$ \\
Velvet bentgrass & $1215 \mathrm{a}$ & $285 \mathrm{a}$ & $65 \mathrm{~b}$ & 73 & $423 \mathrm{a}$ \\
\hline$P$-value & 0.010 & 0.0069 & 0.016 & 0.061 & 0.015
\end{tabular}

${ }^{1}$ Within each column, means followed by the same letter are not significantly different according to Tukey's HSD $_{0.05}$. 
Table 3. Root dry weight for selected turfgrass species on the fairway, June 2009

Values represent means of three replicate samples per species.

\begin{tabular}{lcccccc}
\hline & \multicolumn{5}{c}{ Root dry weight in various layers, $\mathrm{g} \mathrm{m}^{-2}$} \\
\cline { 2 - 6 } & In & Thatch - & & & Total under \\
Turfgrass species & thatch & $5 \mathrm{~cm}$ & $5-10 \mathrm{~cm}$ & $10-20 \mathrm{~cm}$ & thatch \\
\hline Chewings fescue & $1833 \mathrm{a}$ & 289 & $67 \mathrm{~b}$ & $65 \mathrm{ab}$ & $421 \mathrm{ab}$ \\
Slender creeping red fescue & $1834 \mathrm{a}$ & 418 & $44 \mathrm{~b}$ & $18 \mathrm{bc}$ & $480 \mathrm{ab}$ \\
Strong creeping red fescue & $1438 \mathrm{ab}$ & 244 & $70 \mathrm{~b}$ & $33 \mathrm{abc}$ & $348 \mathrm{ab}$ \\
Perennial ryegrass & $977 \mathrm{~b}$ & 400 & $147 \mathrm{a}$ & $69 \mathrm{a}$ & $617 \mathrm{a}$ \\
Kentucky bluegrass & $1179 \mathrm{ab}$ & 190 & $54 \mathrm{~b}$ & $13 \mathrm{c}$ & $258 \mathrm{~b}$ \\
\hline$P$-value & 0.014 & 0.10 & 0.0017 & 0.0091 & 0.027 \\
\hline
\end{tabular}


Table 4. Crop coefficients $(\mathrm{Kc})$ on the first day after irrigation to field capacity and on subsequent days for selected turfgrass species growing on green and fairway. Mean of registration periods 27 May - 2 June 2009, 24 - 30 June 2009, 10-14 Aug. 2009 and 20-30 May 2010.

\begin{tabular}{|c|c|c|c|c|c|}
\hline \multicolumn{3}{|c|}{ Green } & \multicolumn{3}{|c|}{ Fairway } \\
\hline \multirow[t]{2}{*}{$\begin{array}{l}\text { Turfgrass } \\
\text { species }\end{array}$} & \multicolumn{2}{|c|}{$\begin{array}{l}\text { Days after irrigation } \\
\text { to field capacity }\end{array}$} & \multirow[t]{2}{*}{$\begin{array}{l}\text { Turfgrass } \\
\text { species }\end{array}$} & \multicolumn{2}{|c|}{$\begin{array}{c}\text { Days after irrigation } \\
\text { to field capacity }\end{array}$} \\
\hline & $\begin{array}{l}\text { First } \\
\text { day } \\
\text { after }\end{array}$ & $\begin{array}{c}\text { Mean of } \\
\text { following } \\
\text { days }\end{array}$ & & $\begin{array}{c}\text { First } \\
\text { day after }\end{array}$ & $\begin{array}{c}\text { Mean of } \\
\text { following } \\
\text { days }\end{array}$ \\
\hline Chewings fescue & 2.54 & 0.87 & Chewings fescue & $1.82 b^{1}$ & 0.89 \\
\hline Slender creeping red fescue & 2.57 & 0.78 & Slender creeping red fescue & $2.83 \mathrm{a}$ & 0.84 \\
\hline Colonial bentgrass & 2.85 & 0.82 & Strong creeping red fescue & $2.57 \mathrm{a}$ & 0.91 \\
\hline Creeping bentgrass & 2.39 & 0.76 & Perennial ryegrass & $2.67 \mathrm{a}$ & 0.99 \\
\hline Velvet bentgrass & 1.67 & 0.80 & Kentucky bluegrass & $2.29 \mathrm{ab}$ & 0.94 \\
\hline$P$-value & 0.055 & 0.12 & $P$-value & 0.029 & $>0.15$ \\
\hline
\end{tabular}

${ }^{1}$ Within each column, means followed by the same letter are not significantly different according to Tukey's $\mathrm{HS}_{0.05}$. 
Table 5. Turf growth rate $\left(\mathrm{mm} \mathrm{d}^{-1}\right)$ on the green as influenced by irrigation treatment and turfgrass species.

Means of three registration periods in 2009 and one registration period in 2010.

\begin{tabular}{lccc} 
& $\begin{array}{c}\text { Irrigation to } \\
\text { field capacity }\end{array}$ & $\begin{array}{c}\text { No } \\
\text { irrigation }\end{array}$ & Mean $^{1}$ \\
\hline Chewings fescue & 1.49 & 1.21 & $1.35 \mathrm{a}$ \\
Slender creeping red fescue & 1.03 & 0.88 & $0.96 \mathrm{ab}$ \\
Colonial bentgrass & 1.14 & 0.74 & $0.94 \mathrm{abc}$ \\
Creeping bentgrass & 0.61 & 0.41 & $0.51 \mathrm{c}$ \\
Velvet bentgrass & 0.51 & 0.45 & $0.53 \mathrm{bc}$ \\
\hline Mean $^{2}$ & $0.98 \mathrm{~A}$ & $0.74 \mathrm{~B}$ & $0.86^{3}$
\end{tabular}

${ }^{1} P$-value for comparison of species: 0.0003 . Values with the same lower-case letters are not significantly different according to Tukey's $\mathrm{HSD}_{0.05}$.

${ }^{2} P$-value for comparison of irrigation treatments: 0.047 . Values with the same capital letters are not significantly different according to Tukey's HSD $\mathrm{D}_{0.05}$.

${ }^{3} P$-value for interaction: $>0.15$ 
Table 6. Turf growth rate $\left(\mathrm{mm} \mathrm{d}^{-1}\right)$ on the fairway as influenced by irrigation treatment and turfgrass species.

Means of three registration periods in 2009 and one registration period in 2010.

\begin{tabular}{lccc} 
& $\begin{array}{c}\text { Irrigation to } \\
\text { field capacity }\end{array}$ & $\begin{array}{c}\text { No } \\
\text { irrigation }\end{array}$ & Mean $^{1}$ \\
\hline Chewings fescue & 2.05 & 1.52 & 1.78 \\
Slender creeping red fescue & 1.83 & 1.57 & 1.70 \\
Strong creeping red fescue & 2.36 & 1.96 & 2.16 \\
Perennial ryegrass & 2.13 & 1.97 & 2.05 \\
Kentucky bluegrass & 1.48 & 1.58 & 1.53 \\
\hline Mean $^{2}$ & $1.97 \mathrm{~A}$ & $1.72 \mathrm{~B}$ & $1.84^{3}$ \\
\hline
\end{tabular}

${ }^{1} P$-value for comparison of species: 0.065

${ }^{2} P$-value for comparison of irrigation treatments: 0.013 . Values with the same capital letters are not significantly different according to Tukey's $\mathrm{HSD}_{0.05}$.

${ }^{3} P$-value for interaction: $>0.15$. 
Table 7. Turfgrass quality (1-9, 5 is acceptable turf) by the end of registration periods on the green as influenced

by irrigation treatment and turfgrass species. Means of three registration periods in 2009 and one registration period in 2010.

\begin{tabular}{lccc} 
& $\begin{array}{c}\text { Irrigation to } \\
\text { field capacity }\end{array}$ & $\begin{array}{c}\text { No } \\
\text { irrigation }\end{array}$ & Mean $^{1}$ \\
\hline Chewings fescue & 6.3 & 6.0 & $6.2 \mathrm{~b}$ \\
Slender creeping red fescue & 6.9 & 5.8 & $6.4 \mathrm{ab}$ \\
Colonial bentgrass & 7.0 & 6.0 & $6.5 \mathrm{ab}$ \\
Creeping bentgrass & 6.9 & 5.5 & $6.2 \mathrm{~b}$ \\
Velvet bentgrass & 7.4 & 7.3 & $7.3 \mathrm{a}$ \\
\hline Mean $^{2}$ & 6.9 & 6.1 & $6.5^{3}$
\end{tabular}

${ }^{1} P$-value for comparison of irrigation treatments: 0.025 . Values with the same lower-case letters are not significantly different according to Tukey's HSD ${ }_{0.05}$.

${ }^{2} P$-value for comparison of irrigation treatments: 0.14 .

${ }^{3} P$-value interaction: $>0.15$ 
Table 8 . Turfgrass quality (1-9, 5 is acceptable turf) by the end of registration periods on the fairway as influenced by irrigation treatment and turfgrass species. Means of three registration periods in 2009 and one registration period in 2010.

\begin{tabular}{lccc} 
& $\begin{array}{c}\text { Irrigation to } \\
\text { field capacity }\end{array}$ & $\begin{array}{c}\text { No } \\
\text { irrigation }\end{array}$ & Mean $^{1}$ \\
\hline Chewings fescue & 6.7 & 5.7 & 6.2 \\
Slender creeping red fescue & 7.0 & 6.3 & 6.6 \\
Strong creeping red fescue & 6.5 & 5.5 & 6.0 \\
Perennial ryegrass & 7.4 & 6.9 & 7.1 \\
Kentucky bluegrass & 6.5 & 5.6 & 6.0 \\
\hline Mean $^{2}$ & $6.8 \mathrm{~A}$ & $6.0 \mathrm{~B}$ & $6.4^{3}$ \\
\hline
\end{tabular}

${ }^{1} P$-value for comparison of species: $>0.15$.

${ }^{2} P$-value for comparison of irrigation treatments: 0.041 . Values with the same capital letters are not significantly different according to Tukey's HSD $\mathrm{D}_{0.05}$.

${ }^{3} P$-value interaction: $>0.15$ 
Table 9. Actual daily evapotranspiration rates $\left(\mathrm{ET}_{\mathrm{a}}\right)$ measured on green and fairway on the first day after irrigation to field capacity compared with the maximum evaporation equivalents as determined by average daily global radiation at Landvik weather station during the four measurement periods in 2009 and 2010.

\begin{tabular}{lcccc}
\hline & $\begin{array}{c}\text { 27 May -2 } \\
\text { June 2009 }\end{array}$ & $\begin{array}{c}\text { 24 June -2 } \\
\text { July 2009 }\end{array}$ & $\begin{array}{c}\text { 10-14 Aug. } \\
2009\end{array}$ & $\begin{array}{c}\text { 20-30 May } \\
2010\end{array}$ \\
\hline $\mathrm{ET}_{\mathrm{a}}$, mean for all species, green & 7.3 & 8.5 & 7.6 & 11.2 \\
$\mathrm{ET}_{\mathrm{a}}$, mean for all species, fairway & 9.3 & 10.6 & 9.1 & 12.2 \\
Global radiation, MJ m & & & & \\
Evaporation equivalent, mm & 26.5 & 26.0 & 16.8 & 21.7 \\
\hline
\end{tabular}




\section{Green}

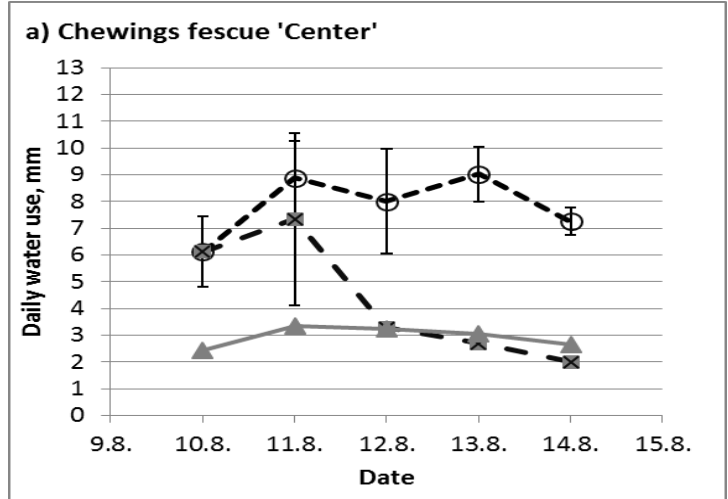

Fairway
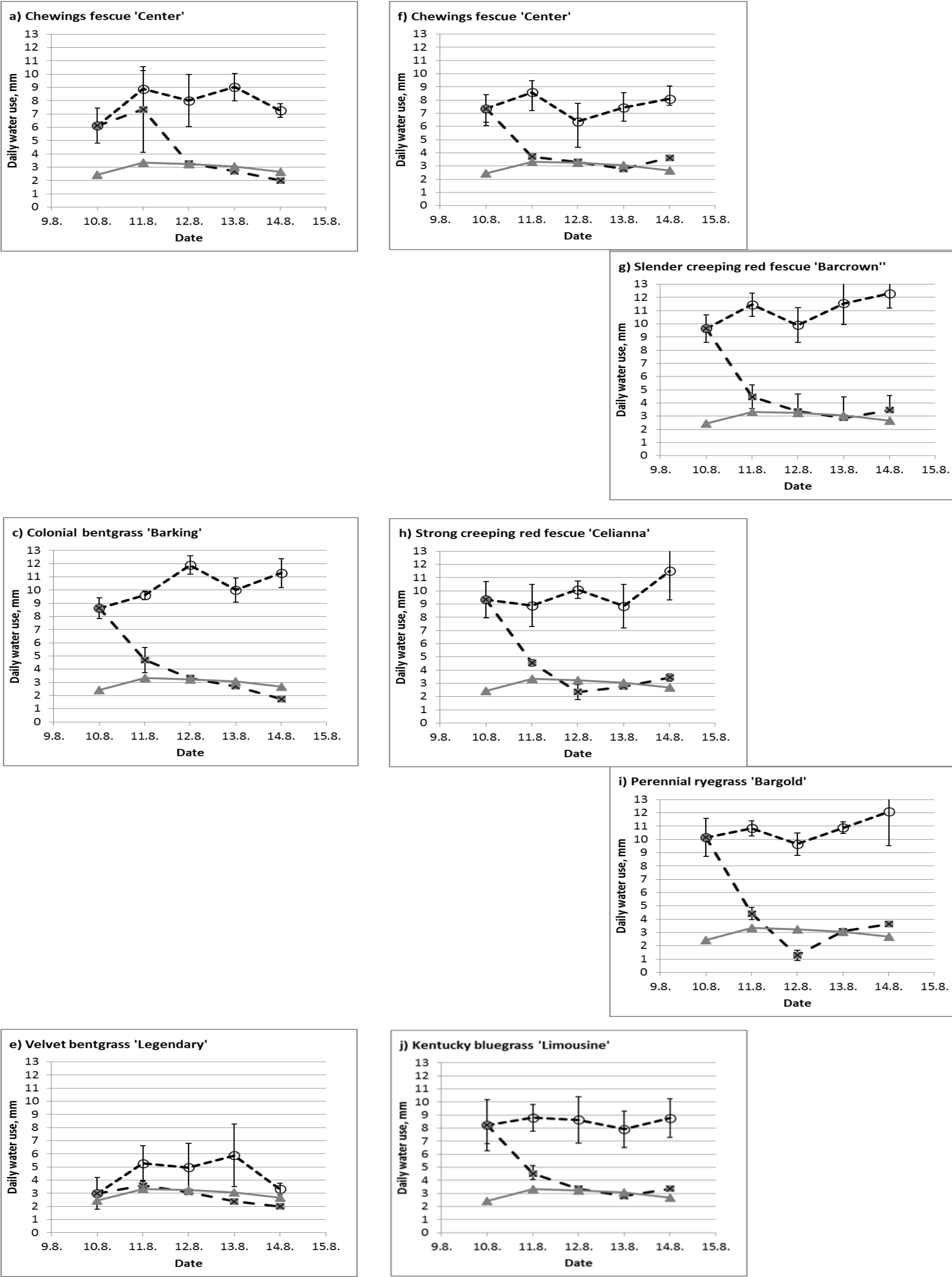


\section{Green}

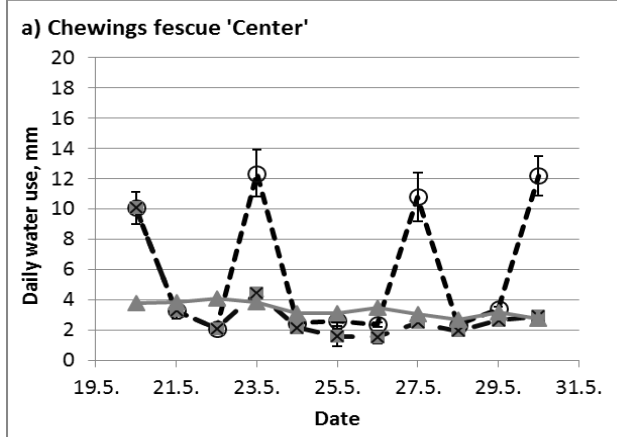

b) Slender creeping red fescue 'Cezanne'

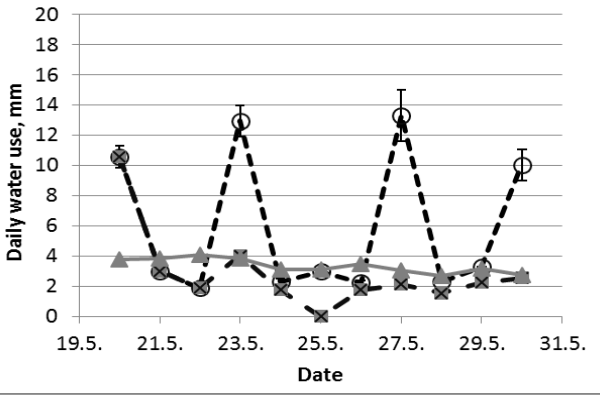

c) Colonial bentgrass 'Barking'
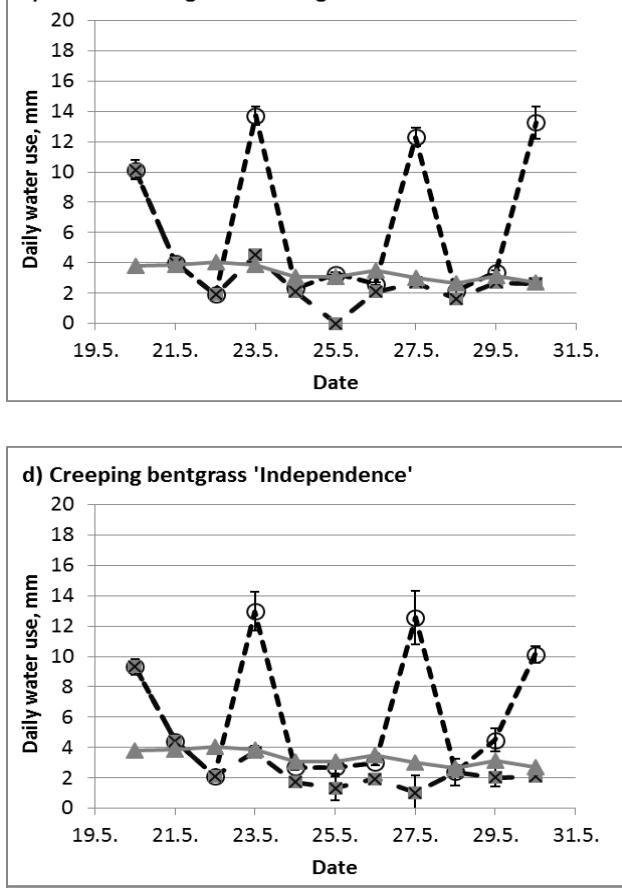

e) Velvet bentgrass 'Legendary'

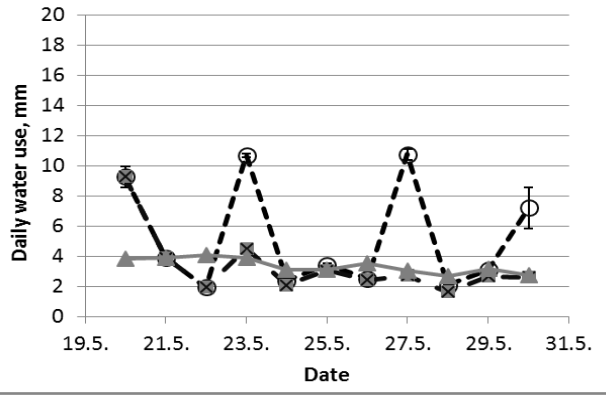

f) Bare soil

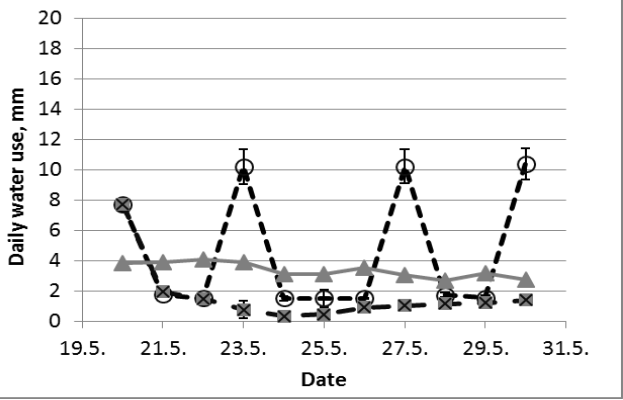

Fairway

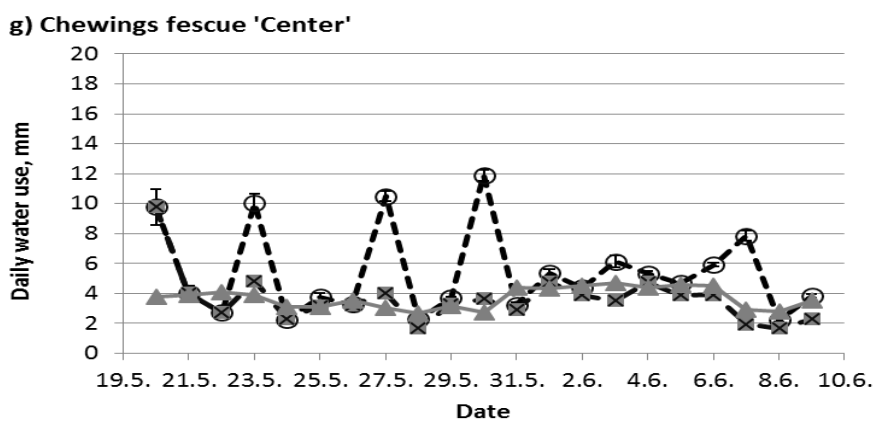

h) Slender creeping red fescue 'Barcrown'

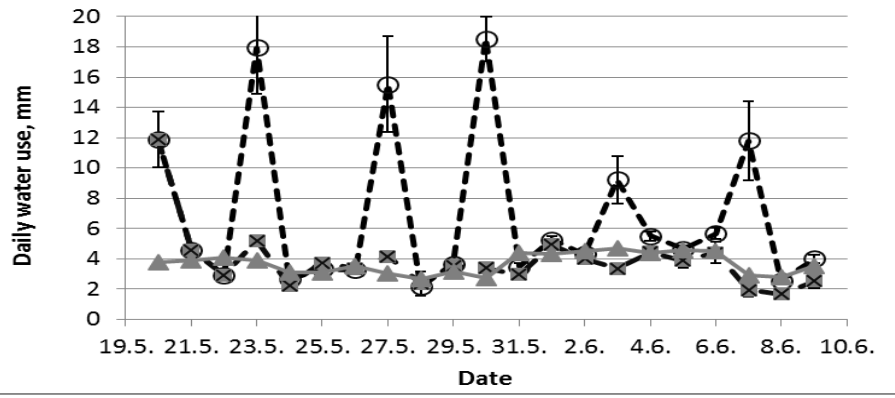

i) Strong creeping red fescue 'Celianna"
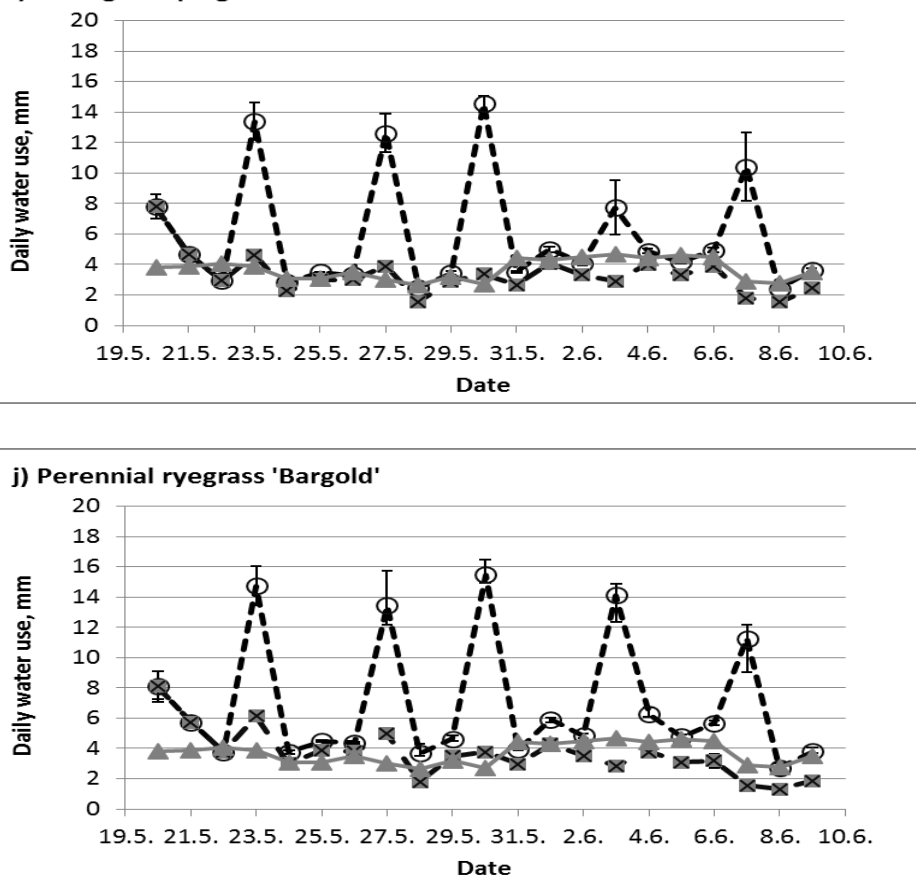

k) Kentucky bluegrass 'Limousine'

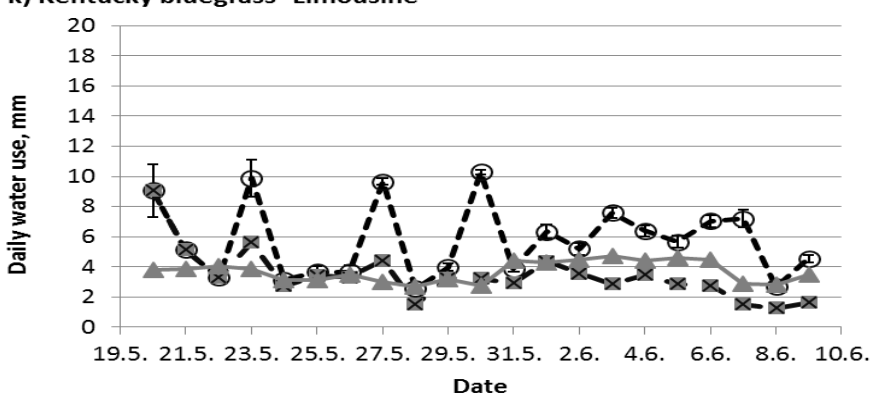

- ๑- Irrigation twice per week

$-x-$ No irrigation

$\longrightarrow$ ETO (FAO 56) 

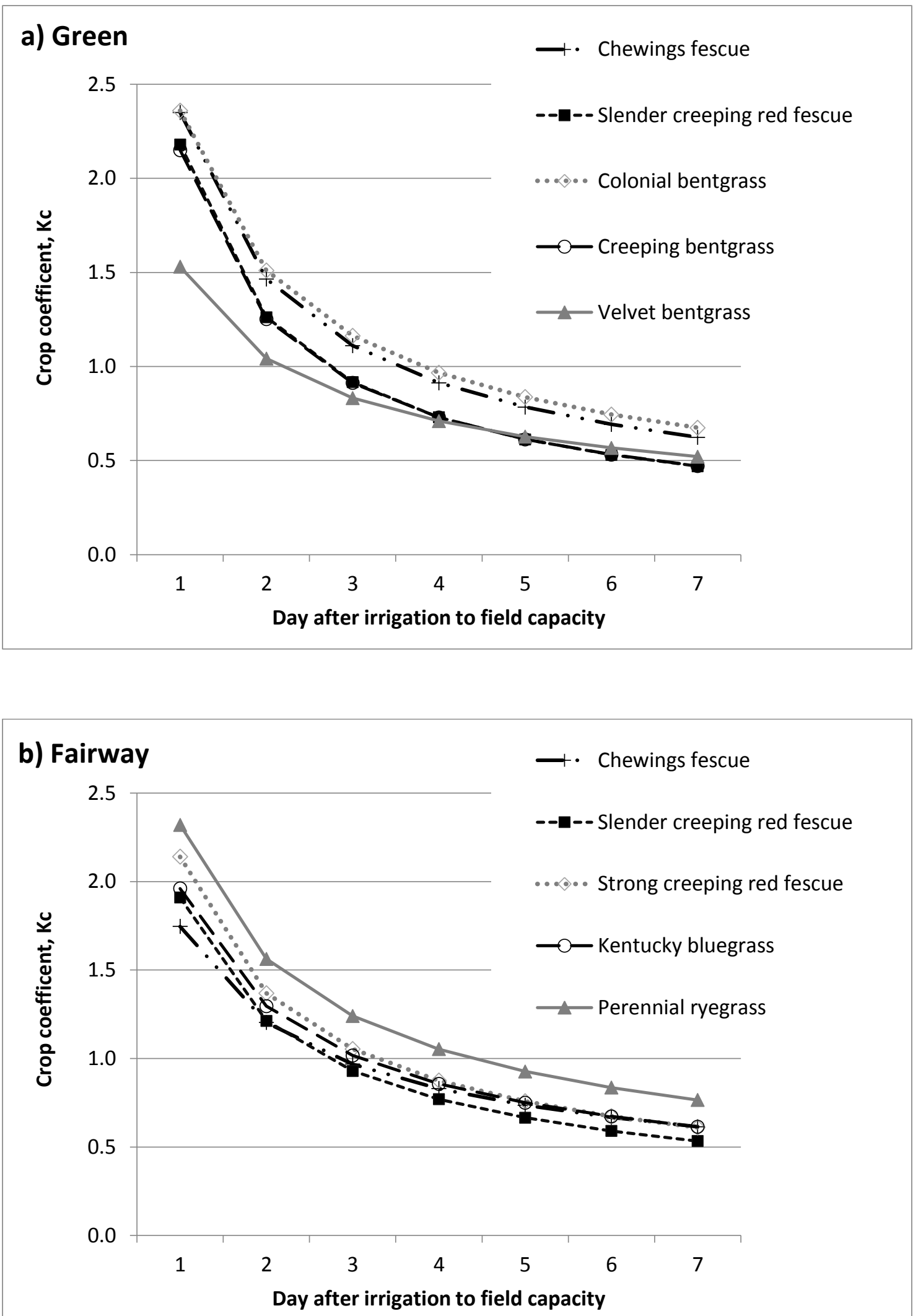